Історико-політичні проблеми сучасного світу: Збірник наукових статей. - Чернівці: Чернівецький національний університет, 2019. - T. 40. - C. 196-206

DOI: $10.31861 / \mathrm{mhpi} 2019.40 .196-206$

УДК: 001.92:321.7](477)
Modern Historical and Political Issues: Journal in Historical \& Political Sciences. - Chernivtsi: Chernivtsi National University, 2019. - Volume. 40. - pp. 196-206 DOI: $10.31861 / \mathrm{mhpi} 2019.40 .196-206$

\title{
Retrospective Analysis of Information Democracy in the Political and Information Space of Ukraine (1991-2018)
}

The article aims to identify the stages of development of informational democracy in Ukraine and analyze the current state of Ukraine's entry the world informational space. The study identifies the following stages: the first stage (1991-1997) - the emergence of informational democracy; the main feature of which is the pluralization of the media, which created the conditions for the occurrence of informational democracy; the second stage (1998-2004) is characterized by informatization of various spheres of vital activity of society and institutions of governance, the beginning of the development of e-democracy and laying the foundations for a technocratic model of informational democracy; the third stage of the development of Ukraine's informational democracy (2005-2009) laid the foundation for the development of digital, network and TVdemocracy; the partnership relations between the government and civil society are developing, which prompts the emergence of a procedural and advisory model of e-democracy, and the fourth stage (2010-2013) - being in conditions close to authoritarian the technocratic and procedural models were found, when problems with an advisory model were found; in addition there was an external threat of military and increased informational intervention. Since 2014, the fifth stage has begun, and as it is incomplete now, its review has not also been completed. In order to solve the problems, a comprehensive approach has been used to identify the trends and patterns of informational democracy. Structural functionalism treats the subject as a system with its structural components, each of which performs its functions. The methodologically important principle of structural and functional analysis is the consideration in a single integrity of the functions and dysfunctions of the institutes. This analysis helped to study the current state of democratic institutions. The political and system analysis provided an opportunity to comprehensively explore the political space as a system of communicative ties.

Key words: information, stages, democracy, e-democracy, ICT, Ukraine, models, development, politics, economics.

\section{Ретроспективний аналіз інформаційної демократії в політичному та інформаційному просторі України (1991-2018 рр.)}

Дану статтю підготовлено відповідно до завдань спільних українсько-польських науководослідних проєктів для реалізації у 2018-2019 рр. «Інформаційна війна як новий вимір геополітичної ривалізації» (номер держреєстрації 0118U006165) спільно з відділом політології Інституту наук про безпеку Краківського педагогічного університету ім. Національної освітньої комісії.

У статті виділено етапи розвитку в Україні інформаційної демократії: 1991-1997 р. зародження інформаційної демократії, 1998-2004 рр. інформатизація різних сфер життєдіяльної суспільства та владних інститутів, початок е-демократії, 2005-2009 pp. - закладено фундамент для розвитку цифрової, мережевої та теледемократії, 2010-2013 pp. - виникають технократична та процесуальна модель, 32014 - виникла зовнішня загроза військової та посилена інформаційна інтервенція. Для вирішення поставлених завдань використано комплексний підхід, який допоміг виявити тенденції та закономірності розвитку інформаційної демократії в умовах соціально-економічної та політичної нестабільності. Доведено, що Україна має власну історію розвитку базових засад інформаційної демократії, в країні сформовано основні правові

\footnotetext{
1 Doctor of Political Sciences, Professor, Lesya Ukrainka Eastern European National University, Ukraine. E-mail: ant80@meta.ua; http://orcid.org/0000-0002-5234-0758.
} 
засади побудови інформаційної демократії шляхом прийняття ряду нормативно-правових актів, які, зокрема, регулюють суспільні відносини у сфері сприяння розвитку громадянського суспільства, створення інформаційних електронних ресурсів, захисту прав інтелектуальної власності на такі ресурси, гарантій та механізму доступу до публічної інформації, розвитку еурядування та відкритого уряду, е-документообігу, інформаційної безпеки тощо. Разом із тим ступінь розбудови і-демократії в Україні порівняно зі світовими тенденціями є недостатнім і не відповідає потенціалу та можливостям України.

Ключові слова: інформація, етапи, демократія, і-демократія, ІКТ, Україна, моделі, розвиток, політика, економіка.

The problem formulation. Nowadays, the post-Soviet countries, including Ukraine, enter the period of democratic states with transparent political systems and open governments, the functioning of which is provided by the information society, an extensive mass media system, and effective ICTs. Political communication has become a key dimension in ensuring the "transparency" of a political decision-making process and an integral attribute of democratic regimes of the present. In Ukraine, the discussion of the issue of the information state has begun relatively recently, Western countries are the pioneers in this sphere, but we as well have achievements and strategic plans regarding the mentioned topic. In order to efficiently develop an information state, it is necessary to investigate the historical stages of the formation and evolution of i-democracy in Ukraine.

Analysis of recent research and publications. Scholars of the European, American and Ukrainian scientific schools have developed the basic notions of information democracy and laid the groundwork for further promising research. We have analyzed publications devoted to the study of the processes of the emergence and development of information democracy, namely, works by K. Arterton, T. Becker and S. Slaton (the concept of tele-democracy), R. Hollander (the concept of video democracy), P. Varley, L. K. Grossman, B. Friedman (the concept of e-democracy) and others. The foreign experience of an information society creation based on democratic principles, gives a clearer and more understandable vision of the information democracy prospects in Ukraine. The basis for the research of information democracy aspects includes the scientific studies of such Ukrainian scholars as O. Holobutskyi, O. Zernetska, M. Zhurovskyi, L. Klymanska, V. Kovalevskyi, Ye. Makarenko, Ye. Tykhomyrova, A. Chychanovskyi, O. Shevchuk, N. Rzhevska and etc. The articles by V. Bebyk ${ }^{2}$, H. Pocheptsov ${ }^{3}$ present suitable and up-to-date approaches to research this issue.

The purpose of the article is to analyze the state of Ukraine's entry into the global information space in the period of its independence and highlight the stages of information democracy development in Ukraine in conditions of socio-economic and political instability.

Main results of the research. The American transitologist S. Huntington introduced the term "wave of democratization" into scientific terminology, denoting the ongoing transition from undemocratic to democratic regimes, and significantly exceeds the number of transitions in the opposite direction. Due to the collapse of the USSR, various models of the political system have developed; since the methodology of democratic transit is quite acceptable for being analyzed. At the beginning of its formation as an independent state, Ukraine fell under the third wave of democratization. Thus, the peak of democratic processes in our country fell on the global third wave of democratization. We assume that this has become one of the reasons for the complication of the democratization process in Ukraine and has led to some negative consequences ${ }^{4}$. Therefore, Ukraine gained a long-awaited independence and an opportunity to enter the group of countries with democratic views and values at a fast pace. The global features of information democracy, in

\footnotetext{
${ }^{2}$ Бебик В. (2009). Глобальний політичний менеджмент: поняття, типологія, методологія. Політичний менеджмент, 2, с. 27-34; Бебик В. М. (2005). Інформаційно-комунікаційний менеджмент у глобальному суспільстві: психологія, технології, техніка наблік рилейшнз. Київ: МАУП, 440 с.; Бебик В. М. (2011). Соціально-комунікаційна праксеологія: поняття і методи. Інформація і право, 2, с. 53-60; Бебик В. М., М'якушко Н. С. (2018). Соціально-політичні аспекти формування інформаційного суспільства України. Гілея: науковий вісник, 130, с. 411-413.

${ }^{3}$ Почепцов Г. (2012). Від FACEBOOK'у і ГЛАМУРУ до WIKILEAKS: медіакомунікації, 464 с.; Почепцов Г. (2016). Сучасні інформаційні війни. Сучасні інформаційні війни, $498 \mathrm{c}$.

${ }^{4}$ Бунецький Л. Л. (2010). Інституційні інновації періоду демократичного транзиту України, URL: http://www.nbuv.gov.ua/portal/natural/vknu/FP/2010_97/p_042_047.pdf.
} 
particular, the internetization of political institutions, the attraction of more citizens to state affairs owing to the use of information democracy, etc., were also characteristic of Ukraine. However, the general decline of the democratization wave could not but affect the political processes in this country; it has influenced the current state of information democracy as the main external indicator of the country's development ${ }^{5}$.

The ambiguity and breadth of the term "information democracy" poses some difficulties in its definition, understanding and interpretation. This category is practically absent in modern post-Soviet interpretations of the global information society, and therefore, there are no approaches to its definition and certain formalization. It is often used to strengthen the general theory of information civilization, without giving a clear understanding of this term, or reducing it only to the known "e" consider information democracy as an objective reality that characterizes the modern development of society. Noteworthy, a French politician and political scientist M. Rocard ${ }^{7}$ introduced the term "information democracy" in 1990. The scientist believes the interdependence between electors, the media and voters is the core of democracy. The novelty of this theory is that the author identified components, i.e., universal suffrage and free information, while pointing out the need for their application without manipulation and deception of political technologists. Naturally, the most just and most democratic citizens can exercise their electoral rights only on condition of free dissemination of information, absence of political bans, censorship, political terror, etc. The detection of the choice of citizens is carried out through the information, therefore, the media are called the "fourth power". We do not support such treatment of media because according to the definition of power, the mass media cannot be called "the power", as they have no legal right to influence events or individuals, and they are not responsible for the decisions made.

The structure of information democracy can be analyzed through its forms. Nowadays, there are a many points of view, so we systematize them on an instrumental basis. The instrumental dimension of such new categories as "tele democracy", "cyber democracy", "virtual democracy", "e-democracy", "digital democracy", "online democracy", "internet democracy", "network democracy", etc. is important for a common understanding of the phenomenon of information democracy. These concepts are associated with measures to increase the political participation of citizens in order to unite them and their representatives in the government precisely through new information and communication technologies. Differences between concepts do not significantly affect the integrity and methodological accuracy of the concept, but allow distinguishing between different technological and procedural aspects in its practical implementation. The evolution of information democracy depends closely on the development of the information space, which has passed several stages in the conditions of economic and political instability of the period of Ukraine's independence (1991-2015), has passed several stages ${ }^{8}$. We have identified such four periods.

Stage 1991-1997 is characterized by the process of the emergence of information democracy. In the first years of Ukraine's independence, the press gained freedom of speech, and although there were financial difficulties and the problem of retraining journalists, the information space was undergoing a truly revolutionary change, i.e., the change of ideological platform, pluralism, the emergence of public relations and advertising that had begun in the mid-1980s long before Ukraine's independence. The destruction of the old system of economic existence of the printed media was the main source of these changes. The state-funded press turned into a press that was economically dependent on other actors; primarily it referred to non-state-owned printed media. An analysis of socio-political, economic, and cultural factors proves that the overall political situation in the country pushed the mass media to reorganization, resulting in independent media. A large number of new printed editions, TV- and radio broadcasting companies of various forms of ownership showed positive processes in the formation of

\footnotetext{
${ }^{5}$ Москаленко А. 3., Качкан В. А. (1990). С чем идем к людям (размышления о современной публицистике). Киев: Лыбидь, 160 с.

6 Ржевська Н. (2010). Вплив інформаційного суспільства на формування категоріального апарату політичної науки: інформаційна демократія як політична категорія. Вісник Львів. ун-ту. Філософськополітологічні студіi, 1, с. 229-236.

${ }^{7}$ Рокар М. (1990). Трудиться с душой. Москва: Междунар. отношения, 339 с.

${ }^{8}$ Митко А. М. (2013). Розвиток інформаційної демократії в Україні. Держава і громадянське суспільство в Украӥні: пошук конщепиії співпращчі: аналіт. доповідь. Київ: ІПіЕНД ім. І.Ф.Кураса НАН України, с.212243.
} 
freedom of speech, but the independence of the media was a remote goal. The analysis of reports in the media confirms that the censorship of the Communist Party shifted to the censorship of private and power structures.

Consequently, on the one hand, the mass media directly contributed to democratic change, and, on the other hand, democratization of the mass media became possible due to democratic transformations in the state ${ }^{9}$. At the end of the period, we are witnessing the emergence of such tools of infodemocracy as Internet sites, blogs, chats, forums. At the same time, there is a decrease in the volume of broadcasting and the share of the wired radio audience, the reduction of the circulation in the printed media both at the national level and in separate regions. Despite the material and technical problems, printed media remain the most popular and authoritative. In a grave difficulty, there is a wired radio, which is superseded by more technically perfect and popular mass media (Table 1).

Media and book publishing in Ukraine (1990-1997) ${ }^{10}$

Table 1

\begin{tabular}{|c|c|c|c|c|c|c|c|c|}
\hline & \multicolumn{2}{|c|}{$\begin{array}{l}\text { Issue of books } \\
\text { and brochures }\end{array}$} & \multicolumn{2}{|c|}{$\begin{array}{l}\text { Issue of magazines } \\
\text { and other periodi- } \\
\text { cals }\end{array}$} & \multicolumn{2}{|c|}{$\begin{array}{l}\text { Number of } \\
\text { newspapers }\end{array}$} & \multicolumn{2}{|c|}{$\begin{array}{c}\text { Average daily } \\
\text { volume of } \\
\text { broadcasting, } \\
\text { hours }\end{array}$} \\
\hline & $\begin{array}{l}\text { Number } \\
\text { of publi- } \\
\text { cations, } \\
\text { printed } \\
\text { units. }\end{array}$ & $\begin{array}{c}\text { Circula- } \\
\text { tion of } \\
\text { editions, } \\
\text { mln. } \\
\text { copies }\end{array}$ & $\begin{array}{l}\text { Number } \\
\text { of print- } \\
\text { ed units }\end{array}$ & $\begin{array}{c}\text { Annual } \\
\text { circula- } \\
\text { tion of } \\
\text { editions, } \\
\text { mln. cop- } \\
\text { ies. }\end{array}$ & $\begin{array}{l}\text { Number } \\
\text { of publi- } \\
\text { cations, } \\
\text { printed } \\
\text { units. }\end{array}$ & $\begin{array}{l}\text { Average } \\
\text { one-time } \\
\text { circula- } \\
\text { tion, } \\
\text { mln. } \\
\text { copies }\end{array}$ & $\begin{array}{c}\text { TV } \\
\text { broad- } \\
\text { casting }\end{array}$ & $\begin{array}{l}\text { Radio } \\
\text { broad- } \\
\text { casting }\end{array}$ \\
\hline 1990 & 7046 & 170 & 185 & 166 & 1787 & 25 & $\ldots$ & $\ldots$ \\
\hline 1991 & 5857 & 136 & 194 & 95 & 1891 & 27 & $\ldots$ & $\ldots$ \\
\hline 1992 & 6389 & 130 & 321 & 16 & 1695 & 24 & $\ldots$ & $\ldots$ \\
\hline 1993 & 5002 & 88 & 522 & 33 & 1757 & 40 & 60,1 & 112,4 \\
\hline 1994 & 4752 & 52 & 461 & 19 & 1705 & 20 & 100,3 & 118,2 \\
\hline 1995 & 6109 & 68 & 604 & 24 & 1877 & 21 & 152,3 & 155,0 \\
\hline 1996 & 6084 & 52 & 717 & 20 & 2206 & 23 & 214,2 & 209,8 \\
\hline 1997 & 6308 & 51 & 817 & 20 & 2520 & 34 & 182,5 & 226,7 \\
\hline
\end{tabular}

The second stage (1998-2004) is the period of extensive development of i-democracy. In the model of transition states, it is called "the stage of neopatrimonialism". This period can also be called the phase of stagnation, statehood establishing and control over the information space by the authorities. For the post-Soviet countries it was the stage of an extensive development of democratic institutions reflected in the development of information democracy. Since the adoption of the Constitution of Ukraine in June 1996 and laws on state support for mass media and social protection of journalists in 1997, a new stage in the history of the information space of Ukraine has begun. In his studies of political journalism D. Dutzyk calls this period "the clanization of the Ukrainian mass media - the beginning of the loss of the conquered freedom" "1. The press accepted the rules by which the leading TV channels and national editions became the property of the oligarchs and political-financial groups. Increasingly, we are witnessing a manifestation of the monopolization of the information sphere by the authorities and the government structures. In the society there was a rather steady demand for state paternalism, which was preconditioned, primarily, by the crisis phenomena in the economy (unemployment, rising inflation, depreciation of savings, etc.). It is clear that in such conditions social disintegration and social depression prevailed, which strengthened the traditional for this society desire for state paternalism, a "strong hand" capable of "bringing order" and ensuring stability. Democracy, thus, went to the background ${ }^{12}$.

\footnotetext{
9 Клименко І. В., Линьов К. О. (2006). Технології електронного урядування. Київ: Вид-во ДУС, 225 с

10 Державна служба статистики України. Офіційний вебсайт, URL: http://www.ukrstat.gov.ua/.

11 Дуцик Д. (2005). Політична журналістика. Київ: Вид. дім «Києво-Могилянська акад.», 138 с.

12 Соснін О. (2012). Інформаційна та комунікаційна компетентність громадянина в процесах формування громадянського суспільства, Віче, 20 (329), 22-26.
} 
The use of the mass media during the election got particular significance, which witnessed the final transformation of the Ukrainian media into propaganda: it is a matter of pro-government and opposition mass media. At this very stage "temnyky" (derived from the word "temnyi", that is "dark"; "temnyky" means those who make everything dark) appeared. The main press and television reports emphasis became the same, and during the 2002 elections there was a huge amount of disinformation. Thus, the Ukrainian media space of this period lost its freedom and independence in covering the political life of the society. The named threats were supplemented by a physical danger to journalists while performing their professional duties.

In 1998, the National Informatization Program (NIP) was adopted in Ukraine. One of its areas is devoted to the creation of departmental information and analytical systems. However, the process really started only in 2000-2001, and more than 30 information and analytical systems of different levels and 20 systems of electronic information resources of the national scale were to be created. The analysis of the real state of computer systems shows a different degree of their adequacy to the tasks assigned to the relevant departments. Insufficient funding appeared to be one of the main constraints on the more intensive construction of information and analytical systems of ministries and departments. H. Pocheptsov and S. Chukut define the period of 2000-2001 as the beginning of edemocracy $^{13}$. At precisely that time the most common aspects of the use of modern ICTs were determined, and the necessary ground for further state action in this direction was formed. In 2002, the State Committee for Communications and Informatization prepared the Electronic Ukraine Program, which defined the priority directions of the strategy aimed at creating the state's information infrastructure; the Program laid the basis for the application of the technocratic model of information democracy in this country.

The use of the latest technological means of disseminating information is the progressive feature of information democracy at the end of 2004; it laid the foundation for such kind of i-democracy as edemocracy. However, the development of computer networks was very weak and there was no control and support from government agencies. The lack of censorship, accessibility, the ability to express personal views confidentially caused the special popularity of the World Wide Web. In general, the period of 1998-2004 became regressive in the development of freedom of speech and independence of mass media. At the same time, mainly during the period of the establishment of private editions and printed media of the state authorities, the number of participants in the printed media doubled, while the TV and radio space remained almost unchanged. 2000-2003 were characterized by the formation of mechanisms of the technocratic model of infodemocracy in Ukraine aimed at increasing the efficiency and transparency of the activities of state authorities and local self-government bodies, improving the awareness of citizens about the activities of these bodies and intensifying the feedback between the state authorities and the society through the Internet.

The third stage of the development of i-democracy in Ukraine covers the period of 2005-2009. It is the stage of rapid recovery of freedom of speech lost in the second half of 19990's, the establishment of new and reorganization of existing members of the media market, the increase of openness of the state authorities, the involvement of the public in power and political processes. At this stage building relations between government and society is likely to have a partner character. These factors have laid the basis for the information state. To our mind, the beginning of this stage is connected with the events of the "Orange Revolution", which changed the outcome of the presidential election in Ukraine. Under such circumstances, ICTs received a credibility loan and became an important tool for obtaining and retaining power by local authorities.

Accordingly, we will demonstrate the development of i-democracy in the third stage of the infodemocracy evolution, based on indices. Among all the 180 countries included in the ranking, Ukraine occupied the $93^{\text {rd }}$ position and was among the fifth group of countries with a digital capability index of 0.30 to 0.40. Together with Ukraine, Georgia, Azerbaijan, Oman, Thailand, Lebanon, Algeria, Tunisia were included in this group. Concerning the position of Ukraine in the pan-European dimension, it was in the top three outsiders. Analyzing the reasons for such a low position, one can

\footnotetext{
13 Чукут С. Почепцов Г. (2003). Сутність електронного уряду та принципи його організації. Вісн. УАДУ, 2 , c. $429-433$.
} 
notice that Ukraine's evaluation of indicators belonging to the Index component entitled "Usage" is especially negative for Ukraine ${ }^{14}$.

Another international index that compares Ukraine and other countries to the level of development of information democracy is the e-readiness index, which is determined annually for 68 countries by 36 indicators. In cluster-spectral analysis, according to the dynamics of the e-readiness index during 2004-2006, Ukraine competed with Nigeria for the $60^{\text {th }}$ position in this ranking, and in 2006 the latter outstripped Ukraine by several hundredths ${ }^{15}$. According to the Digital Planet 2006, published by the World Information Technologies and Services Alliance (WITSA), among the countries of Western, Eastern Europe, Ukraine was on the last position in terms of per capita GDP and on the penultimate position according to the indicator of spending on ICT per capita (in front of Bulgaria) - \$141 USA. Simultaneously, the main funds were directed at the development of networks and communications. It is worth mentioning that Ukraine's neighbors spent much more on ICT: Russia - \$ 192 USA, Romania $-\$ 164$ USA, Poland - \$328 USA per capita ${ }^{16}$.

In 2002-2007, the dynamics of the e-government index showed a slowdown. If we compare the index of development of i-democracy in the context of the indicators, the situation in this country is not much inferior to the average level within the East European region and even exceeds the average world values. However, in comparison with regional leaders' being Internet-savvy, one can observe a significant lag behind all indicators, except for the index of human capital.

In 2009, the elaboration of the Law of Ukraine "On the Concept of State Information Policy" was aimed at ensuring the constitutional right of everyone to receive, collect, store and disseminate information; express personal opinion freely, including in the media; ensure the development of civil society and its democratic institutions. Of particular interest was free and unhindered functioning of the media; as well as create a public broadcasting system and promote the development of socially responsible journalism.

These provisions promote the development of such types of i-democracy as tele democracy, edemocracy, digital democracy. By 2008, electronic consultation tools $(61 \%)$ and citizens' online access to information (53\%) had been the most fully used in Ukraine. Somewhat worse were indicators in the field of public involvement in decision-making $(38 \%)^{17}$. Particular attention should be paid to young people, who easily adapt to the new conditions of the information society, learn quickly and use the tools of infodemocracy. The improvement of information infrastructure promotes the development of i-democracy. Important provisions in this area are outlined in the national program Electronic Ukraine for 2004-2012.

On the next stage of 2010-2014, some progress was made in implementing the Action Plan on the implementation of the Concept of e-Government Development in Ukraine, and the formation of a regulatory framework for the development of information democracy was continued. As it was estimated, Ukraine's ratings, based on the implementation of ICT throughout the years under study were as followed: Global Competitiveness Index 2011-2012 - the $82^{\text {nd }}$ position among 142 countries; Technology Readiness Index 2011-2012 - the 82 ${ }^{\text {nd }}$ position among 142 states; 2011-2012 Network Readiness Index - the $75^{\text {th }}$ position among 142 states; government readiness - the $122^{\text {nd }}$ position among 138 states; use of information and communication technologies by the government - the $75^{\text {th }}$ position among 138 states; E-readiness rating 2010 - the $64^{\text {th }}$ position among 70 countries; the index of the United Nations e-Government 2012 - the $68^{\text {th }}$ position among 193 states $^{18}$.

In the early 2010's, almost one third of Ukrainians were Internet users, new forms of communication, in particular, "social media", had been increasingly mastered; i.e., about 7-8 million of our compatriots had been involved. This fact proves that in Ukraine a massive Internet audience and a specific "network" socio-cultural environment have been created. Since 2009-2010 Ukrainian

\footnotetext{
${ }^{14}$ Аналіз тенденцій світового досвіду побудови інформаційного суспільства, URL: http://www.ecsor.com. ua/files/ indicator_r1.pdf.

15 Митко А.М. (2018). Застосування інформаційно-комунікаційних технологій у підготовці кадрів для інформаційно-аналітичної та політичної сфер. Інформаційні технології і засоби навчання, 65(3), с. 291303. DOI: https://doi.org/10.33407/itlt.v65i3.2004.

${ }^{16}$ Митко А. М. (2011). Перспективи функціонування електронного. Наука и образование XXI века: в 2-х томах. Т. 1. Рязань, СТИ, с. 187-194.

17 Державна служба статистики України. Офіційний вебсайт, URL: http://www.ukrstat.gov.ua/.

18 Почепцов Г. (2016). Сучасні інформаційні війни. 498 с.
} 
politicians have started to use social networks, primarily Facebook and Twitter as a medium of political communication. That was a period of creating the first accounts / profiles of politicians and political parties. In 2010, Facebook posted official pages of the Verkhovna Rada (Supreme Council) of Ukraine, the Ministry of Infrastructure, the Ministry of Culture and the Ministry of Foreign Affairs. During the parliamentary election campaign in 2012, party representation increased in social networks. However, this communication channel was practically not used (as evidenced by the predominant lack of comments and a small amount of preference or tweets) as a tool of political influence on voters.

Internet resources in state governments bodies ${ }^{19}$

Table 2

\begin{tabular}{|l|c|c|}
\hline \multicolumn{1}{|c|}{ Issues } & $\begin{array}{c}\text { The central } \\
\text { bodies }\end{array}$ & $\begin{array}{c}\text { Territorial } \\
\text { subdivisions }\end{array}$ \\
\hline \multicolumn{2}{|c|}{ Data referring websites } \\
\hline Total number of websites & 167 & 1315 \\
\hline Number of websites of structural units & 79 & 137 \\
\hline $\begin{array}{l}\text { Number of websites of enterprises, institutions and } \\
\text { organizations included in the sphere of governance }\end{array}$ & 351 & 176 \\
\hline \multicolumn{2}{|c|}{ Domain Name Data } \\
\hline Total number of registered domain names & 347 \\
\hline $\begin{array}{l}\text { Total number of registered domain names in the domain } \\
\text { gov.ua }\end{array}$ & 157 \\
\hline $\begin{array}{l}\text { Number of registered domain names in the domain } \\
\text { gov.ua used by enterprises, institutions and } \\
\text { organizations included in the sphere of governance }\end{array}$ & 67 \\
\hline
\end{tabular}

Ukraine was among the first states that started the transition to the latest communication standards, i.e., those that develop the fourth generation (4G) of mobile communication networks ${ }^{20}$. In 2013 , the Strategy for the Information Society Development in Ukraine was approved. This Strategy defines the purpose, the basic principles, the strategic goals of the development of the information society in Ukraine, the tasks aimed at their achievement, as well as the main directions, stages and mechanism of the implementation of this Strategy, taking into account the current trends and peculiarities of Ukraine's development prospects up to 2020.

Since 2015, the modern stage of the i-democracy development has begun, which is associated with the need to conduct a hybrid (information warfare) warfare and to establish the Ministry of Information Policy, one of the tasks of which is the implementation of the information security program, the confrontation of the information aggression of other states and prevention of external influence on the information space of Ukraine. The relevance of this Ministry, in our opinion, is obvious. Instead, media experts oppose the creation of this structure and consider it a rudiment of the authoritarian system. Primarily, they refer to the experience of democratic countries where such bodies are not acceptable ${ }^{21}$.

\footnotetext{
${ }^{19}$ Москаленко А. З., Качкан В. А. (1990). С чем идем к людям (размышления о современной публицистике). Киев: Лыбидь, 160 с.

20 Vodafone Украина начал готовить сеть к запуску 4G, до конца следующего года новое LTEоборудование получат 3500 базовых станций оператора (2017, 09.18), URL: https://itc.ua/news/vodafoneukraina-nachal-gotovit-set-k-zapusku-4g-do-kontsa-sleduyushhego-goda-novoe-oborudovanie-poluchat-3500bazovyih-stantsiy-operatora.

${ }^{21}$ Митко А.М. (2018). Застосування інформаційно-комунікаційних технологій у підготовці кадрів для інформаційно-аналітичної та політичної сфер. Інформаційні технології і засоби навчання, 65(3), с. 291303. DOI: https://doi.org/10.33407/itlt.v65i3.2004.
} 
Nowadays, the stage is not completed, but we can single out the following features of the modern stage:

1. The lack of systemic and mutually beneficial communication in the triangle "society - media authorities", although this kind of communication is the fundamental basis for the existence of any developed democracy.

2. Monopolization of media markets. Predominantly, it concerns the broadcasting market, which is already divided between large and several smaller media groups, and, to a lesser extent, the press market. At the same time, relations of ownership of key domestic media remain opaque and insufficiently controlled by the state, and the legislative regulation of this sphere is not sufficiently effective.

3. The lack of a public service broadcasting sector, i.e., a public counterbalance to private media, aimed at ensuring a balanced, dual nature of the national media system. World experience shows that developed structures of public broadcasting are an integral part of modern democracy, a condition and an indicator of its successful development.

4. Insufficient professional level of Ukrainian journalism, undeveloped corporate ethics. Such a situation ultimately affects both the quality of the domestic media product and the adoption of the principles of freedom of speech, objectivity, commitment to the public interest in the Ukrainian media.

5. Excessive number of politically engaged and negative messages in the information space of Ukraine. The inadequate level of public responsibility of the media, incomplete awareness of their own social function are among the reasons for these phenomena.

6. Unevenness and unequal conditions for access to information of different regions, that is, the existence of zones of low informational saturation and "white spots" on the information map of Ukraine due to the lack of capacity and the number of transmitters of domestic TV and radio broadcasters.

7. Delay and difficulties in switching to digital broadcasting format.

8. Poor infrastructure is the key obstacle to development of the information society and defines the prospects for the development of e-democracy.

9. Fragmentation and segmentation of the national information space, which leads to a huge lag of most states behind the level of developed democracies and, as a result, to limited access to information resources.

The "globality" of the Internet and its use in all spheres of life are an important feature of this stage. However, we find out that they are actually used (apart from entertainment content) only by a few segments of the population, while broad masses having no the financial, technical capacity or simply having no skills to work in the Internet remain outside the "global hugs" of the network. Despite the fact that most people have mobile devices, phones, iPads, laptops and computers, and all of them in the vast majority have access to the Internet, only 58\% of the Ukrainian population (or 25.59 million Ukrainians) use the Internet with socio-political goals. Such data were released by the international agency "We are social", which specializes in media research, in the Digital in 2018 Report. Mobile Internet is used by 18.7 million Ukrainians, that is $42 \%$ of the population. Social networks are used by $29 \%$ of the population of Ukraine - 13 million people; among them $22 \%$ of ( 9.5 million) use a mobile phone in the social network. According to statistics, every day $72 \%$ of users use the internet, at least once a week $-21 \%$, at least once a month $-4 \%$, less often than once per month $-2 \%$ of users ${ }^{22}$.

Since we consider this stage unfinished, the topic of information security and the development of modern ICTs, the use of social networks for the political system is relevant and promising, so, it implies further research on this topic.

Conclusions. Ukraine has got its own history of evolution of the information democracy basic principles: the development of concepts and programs of informatization; creation of various ICTs and nationwide electronic information and analytical systems of different levels and purposes. Importantly, the basic legal principles of building information democracy have been molded, in the process of adopting a number of normative and legal acts to regulate, in particular, PR in the domain of promoting Knowledge society. Its crucial tools are the creation of information electronic resources, protection

\footnotetext{
22 Митко А.М. (2018). Застосування інформаційно-комунікаційних технологій у підготовці кадрів для інформаційно-аналітичної та політичної сфер. Інформаційні технології і засоби навчання, 65(3), с. 291303. DOI: https://doi.org/10.33407/itlt.v65i3.2004.
} 
of intellectual property, guarantees and mechanisms for access to public information, development of e-governance and open government, e-document circulation, information security, etc. However, in comparison with world tendencies, the degree of development of i-democracy in Ukraine is insufficient and does not correspond to the potential and capabilities of Ukraine. The top priority of information democracy development in Ukraine is to promote creating, using and sharing information, producing quality goods and services, whilst contributing to the country's sustainable development, based on the purposes and principles proclaimed by the United Nations, the Declaration of Principles and the Action Plan drawn up at the World Summit on the Information Society.

\section{Список джерел}

1. Аналіз тенденцій світового досвіду побудови інформаційного суспільства, URL: http://www.ecsor.com.ua/files/indicator_r1.pdf.

2. Бебик В. (2009). Глобальний політичний менеджмент: поняття, типологія, методологія. Політичний менеджмент, 2, с. 27-34.

3. Бебик В. М. (2005). Інформаційно-комунікаційний менеджмент у глобальному суспільстві: психологія, технології, техніка наблік рилейшнз. Київ: МАУП, 440 с.

4. Бебик В. М. (2011). Соціально-комунікаційна праксеологія: поняття і методи. Інформащія і право, 2, с. 53-60.

5. Бебик В. М., М'якушко Н. С. (2018). Соціально-політичні аспекти формування інформаційного суспільства України. Гілея: науковий вісник, 130, с. 411-413.

6. Бунецький Л. Л. (2010). Інституційні інновації періоду демократичного транзиту України, URL: http://www.nbuv.gov.ua/portal/natural/vknu/FP/2010_97/p_042_047.pdf.

7. Державна служба статистики України. Офіційний вебсайт, URL: http://www.ukrstat. gov.ua/. $138 \mathrm{c}$.

8. Дуцик Д. (2005). Політична журналістика. Київ: Вид. дім «Києво-Могилянська акад.»,

9. Електронна демократія: сподівання та проблеми (2009) / Дж. Кедді, К. Вергез та ін. Київ: Центр адаптації державної служби до стандартів Свропейського Союзу, 164 с.

10. Історія політичної думки (2014) / за заг. ред. Н. М. Хоми. Львів: ПП «Новий Світ-2000», $766 \mathrm{c}$.

11. Клименко І. В., Линьов К. О. (2006). Технології електронного урядування. Київ: Вид-во ДУС, $225 \mathrm{c}$.

12. Митко А. М. (2011). Перспективи функціонування електронного. Наука и образование XXI века : в 2-х томах. Т. 1. Рязань, СТИ, с. 187-194.

13. Митко А. М. (2012). Трансформація інформаційного простору Волині. Волинь в умовах демократичної трансформації (кінець XX cm. - початок XXI cm.). Луцьк: Східноєвроп. нац. унт ім. Лесі Українки, с. 296-317.

14. Митко А. М. (2013). Розвиток інформаційної демократії в Україні. Держава і громадянське суспільство в Україні: пошук концепції співпраці: аналіт. доповідь. КИїВ: ІПіЕНД ім. І.Ф.Кураса НАН України, с. 212-243.

15. Митко А.М. (2018). Застосування інформаційно-комунікаційних технологій у підготовці кадрів для інформаційно-аналітичної та політичної сфер. Інформаційні технології $і$ засоби навчання, 65(3), с. 291-303. DOI: https://doi.org/10.33407/itlt.v65i3.2004.

16. Москаленко А. 3., Качкан В. А. (1990). С чем идем к людям (размышления о современной публицистике). Киев: Лыбидь, 160 с.

17. Почепцов Г. (2012). Від FACEBOOK'у і ГЛАМУРУ до WIKILEAKS: медіакомунікації, $464 \mathrm{c}$.

18. Почепцов Г. (2016). Сучасні інформаційні війни. Сучасні інформаційні війни, 498с.

19. Про схвалення Стратегії розвитку інформаційного суспільства в Україні (2013): розпорядження від 15 травня № 386-p, Офічійний вебпортал Верховної Ради Украӥни, URL: http://zakon1.rada.gov.ua/laws/show/386-2013-\%D1\%80.

20. Ржевська Н. (2010). Вплив інформаційного суспільства на формування категоріального апарату політичної науки: інформаційна демократія як політична категорія. Вісник Львів. ун-ту. Філософсько-політологічні студї, 1, с. 204-213.

21. Рокар М. (1990). Трудиться с душой. Москва: Междунар. отношения, 339 с. 
22. Сейлеханов $€$. Демократичний транзит, URL: http://www.baiterek.kz/index.php? journal $=34 \&$ page $=571$.

23. Соснін, О. (2012). Інформаційна та комунікаційна компетентність громадянина в процесах формування громадянського суспільства, Biче, 20 (329), 22-26.

24. Соснін, О. (2012). Про право громадян на інформацію в сучасному суспільстві. Віче, 8 , 24-27.

25. Соснін, О. В. (2016). Проблеми зростаючої ролі інформаційно-комунікаційної функції держави в умовах інформаційного суспільства та шляхи їх вирішення. Гуманітарний вісник Запорізької державної інженерної академії. 65, 164-176.

26. Чукут С. (2003). Сутність електронного уряду та принципи його організації. Вісн. УАДУ, 2, c. 429-433.

27. International and National Security: Politics, Information, Ecology, Economy (2018) / ed. by A. Mytko. Kyiv: MPBP "Hordon”, 320 p.

28. Vodafone Украина начал готовить сеть к запуску 4G, до конца следующего года новое LTE-оборудование получат 3500 базовых станций оператора $(2017,09.18)$, URL: https://itc.ua/news/vodafone-ukraina-nachal-gotovit-set-k-zapusku-4g-do-kontsa-sleduyushhego-godanovoe-oborudovanie-poluchat-3500-bazovyih-stantsiy-operatora.

\section{References}

1. Analiz tendentsii svitovoho dosvidu pobudovy informatsiinoho suspi-lstva, URL: http://www.ecsor.com.ua/files/indicator_r1.pdf.

2. Bebyk V. (2009). Hlobalnyi politychnyi menedzhment: poniattia, typo-lohiia, metodolohiia. Politychnyi menedzhment, 2, s. 27-34.

3. Bebyk V. M. (2005). Informatsiino-komunikatsiinyi menedzhment u hlobalnomu suspilstvi: psykholohiia, tekhnolohii, tekhnika nablik ry-leishnz. Kyiv: MAUP, $440 \mathrm{~s}$.

4. Bebyk V. M. (2011). Sotsialno-komunikatsiina prakseolohiia: poniattia i metody. Informatsiia $i$ pravo, 2, s. 53-60.

5. Bebyk V. M., Miakushko N. S. (2018). Sotsialno-politychni aspekty formuvannia informatsiinoho suspilstva Ukrainy. Hileia: naukovyi visnyk, 130, s. 411-413.

6. Bunetskyi L. L. (2010). Instytutsiini innovatsii periodu demokratych-noho tranzytu Ukrainy, URL: http://www.nbuv.gov.ua/portal/natural/vknu/FP/2010_97/p_042_047.pdf.

7. Derzhavna sluzhba statystyky Ukrainy. Ofitsiinyi veb-sait, URL: http://www.ukrstat.gov.ua/.

8. Dutsyk D. (2005). Politychna zhurnalistyka. Kyiv: Vyd. dim «Kyievo-Mohylianska akad.», 138 s.

9. Elektronna demokratiia: spodivannia ta problemy (2009) / Dzh. Keddi, K. Verhez ta in. Kyiv: Tsentr adaptatsii derzhavnoi sluzhby do standar-tiv Yevropeiskoho Soiuzu, $164 \mathrm{~s}$.

10. Istoriia politychnoi dumky (2014) / za zah. red. N. M. Khomy. Lviv: PP «Novyi Svit-2000», $766 \mathrm{~s}$.

11. Klymenko I. V., Lynov K. O. (2006). Tekhnolohii elektronnoho uria-duvannia. Kyiv: Vyd-vo DUS, $225 \mathrm{~s}$.

12. Mytko A. M. (2011). Perspektyvy funktsionuvannia elektronnoho. Nauka y obrazovanye XXI veka: v 2-kh tomakh. T. 1. Riazan, STY, s. 187-194.

13. Mytko A. M. (2012). Transformatsiia informatsiinoho prostoru Volyni. Volyn v umovakh demokratychnoi transformatsii (kinets KhKh st. - pochatok KhKhI st.). Lutsk: Skhidnoievrop. nats. un-t im. Lesi Ukra-yinky, s. 296-317.

14. Mytko A. M. (2013). Rozvytok informatsiinoi demokratii v Ukraini. Derzhava i hromadianske suspilstvo v Ukraini: poshuk kontseptsii spiv-pratsi: analit. dopovid. Kyiv: IPiEND im. I.F.Kurasa HAH Ukrainy, s. 212-243.

15. Mytko A.M. (2018). Zastosuvannia informatsiino-komunikatsiinykh tekhnolohii u pidhotovtsi kadriv dlia informatsiino-analitychnoi ta po-litychnoi sfer. Informatsiini tekhnolohii $i$ zasoby navchannia, 65(3), s. 291-303.

16. Moskalenko A. Z., Kachkan V. A. (1990). S chem idem k liudiam (razmyshlenyia o sovremennoi publytsystike). Kiev: Lybid, $160 \mathrm{~s}$.

17. Pocheptsov H. (2012). Vid FACEBOOKu i HLAMURU do WIKILEAKS: mediakomunikatsii, $464 \mathrm{~s}$. 
18. Pocheptsov H. (2016). Suchasni informatsiini viiny. Suchasni infor-matsiini viiny, $498 \mathrm{~s}$.

19. Pro skhvalennia Stratehii rozvytku informatsiinoho suspilstva v Ukraini (2013): rozporiadzhennia vid 15 travnia № 386-r, Ofitsiinyi veb-portal Verkhovnoi Rady Ukrainy. URL: http://zakon1.rada.gov.ua/laws/show/386-2013-\%D1\%80.

20. Rzhevska N. (2010). Vplyv informatsiinoho suspilstva na formu-vannia katehorialnoho aparatu politychnoi nauky: informatsiina de-mokratiia yak politychna katehoriia. Visnyk Lviv. un-tu. Filosofsko-politolohichni studii, 1, s. 229-236

21. Rokar M. (1990). Trudytsia s dushoi. Moskva: Mezhdunar. otno-shenyia, 339 s.

22. Seilekhanov Ye. Demokratychnyi tranzyt, URL: http://www.baiterek.kz/index.php? journal $=34 \&$ page $=571$.

23. Sosnin O. (2012). Informatsiina ta komunikatsiina kompetentnist hromadianyna $\mathrm{v}$ protsesakh formuvannia hromadianskoho suspilstva, Viche, 20 (329), 22-26. 27.

24. Sosnin, O. (2012). Pro pravo hromadian na informatsiiu v suchasnomu suspilstvi. Viche, 8, 24-

25. Sosnin O. V. (2016). Problemy zrostaiuchoi roli informatsiino-komunikatsiinoi funk-tsii derzhavy $\mathrm{v}$ umovakh informatsiinoho suspilstva ta shliakhy yikh vyrishennia. Humanitarnyi visnyk Zaporizkoi derzhavnoi inzhenernoi akademii. 65, 164-176.

26. Chukut S. (2003). Sutnist elektronnoho uriadu ta pryntsypy yoho orhanizatsii. Visn. UADU, 2 , s. 429-433.

27. International and National Security: Politics, Information, Ecology, Economy (2018) / ed. by A. Mytko. Kyiv: MPBP "Hordon", 320 p.

28. Vodafone Ukrayna nachal hotovyt set k zapusku 4G, do kontsa sleduiushcheho hoda novoe LTE-oborudovanye poluchat 3500 bazovykh stantsyi operatora $(2017,09.18)$, URL: https://itc.ua/news/vodafone-ukraina-nachal-gotovit-set-k-zapusku-4g-do-kontsa-sleduyushhego-godanovoe-oborudovanie-poluchat-3500-bazovyih-stantsiy-operatora. 